Perspective

\title{
Lithium-ion Battery and the Future
}

Eugene Stephane Mananga ${ }^{1,2,3, *}$

1. The Graduate Center, The City University of New York, 365 Fifth Avenue, New York, NY, 10016, USA; E-Mail: emananga@gradcenter.cuny.edu

2. Department of Engineering, Physics, and Technology, Bronx Community College, The City University of New York, 2155 University Avenue, Bronx, NY 10453, USA; E-Mail: eugene.mananga@bcc.cuny.edu

3. Department of Applied Physics, New York University, 6 Metro-tech Center, Brooklyn, New York 11201, USA; E-Mail: eugene.mananga@nyu.edu

* Correspondence: Eugene Mananga; E-Mails: emananga@gradcenter.cuny.edu; eugene.mananga@bcc.cuny.edu; esm041@mail.harvard.edu

Academic Editor: Hossein Hosseinkhani

Recent Progress in Materials

2021, volume 3, issue 2

doi:10.21926/rpm.2102012
Received: December 26, 2020

Accepted: March 25, 2021

Published: April 14, 2021

Light-matter interaction at the nanometer scale lies at the heart of many physical problems including spectroscopic techniques to characterize lithium-ion batteries (LIBs). One of the most important topics in time-dependent quantum mechanics for physicists and chemists is the description of spectroscopy, which refers to the study of matter through its interaction with light fields. Classically, light-matter interactions are a result of an oscillating electromagnetic field resonantly interacting with charged particles. Quantum mechanically, light fields will act to couple quantum states of the matter. Light-matter interactions are fundamentally quantum electrodynamical. In many cases, they are described as quantum transitions by electrons, accompanied by the emission, absorption or scattering of quanta of photons [1]. Over the past few decades, several experiments have investigated electromagnetic waves' interaction with various materials used in LIBs for the benefit of society [2-4]. Currently, research in the battery community

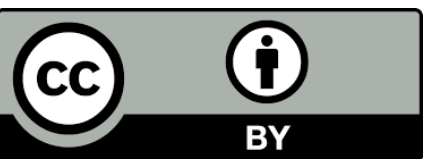

(C) 2021 by the author. This is an open access article distributed under the conditions of the Creative Commons by Attribution License, which permits unrestricted use, distribution, and reproduction in any medium or format, provided the original work is correctly cited. 
is still extensive due to novel techniques and their applications in LIBs and beyond [5]. Usually, one technique is not sufficient to fully characterized LIB materials. One needs to combine more than one technique to characterize one single material [6-9]. When several techniques are used to characterize one type of material, these techniques are applied at different timescales and periods. This fact must be taken into consideration when analyzing data of different techniques obtained at different life span of the material [10-14].

Batteries are devices that transform chemical energy into electricity and consist of electrochemical cells that are electrically connected [15]. Historically, the modern battery was developed by Alessandro Volta in 1800 [16]. Shortly after Volta, Gaston Plante invented the leadacid battery in 1859 [17]. As time went by, Georges Leclanche introduced the zinc-carbon battery (Leclanche cell) in 1866, which is one of the first modern electric batteries and the precursor of the modern dry cell battery [18]. In 1899, Ernst Jungner invented the nickel-cadmium battery (NiCd) [19]. The effort on nickel metal hybrid (NiMH) batteries began at the Battelle-Geneva Research Center following the technology's invention in 1967. An interest grew in the 1970s with the commercialization of the nickel-hydrogen battery for satellite applications [20]. Research carried out by the CNRS in France and the Philips Laboratories developed new high-energy hybrid alloys incorporating rare-earth metals for the negative electrode [21]. However, these high-energy hybrid alloys suffered from alloy instability in alkaline electrolyte and consequently insufficient cycle life. The first consumer-grade NiMH cells became commercially available in 1989 [22]. In 2008, more than two million hybrid cars worldwide were manufactured with $\mathrm{NiMH}$ batteries. The battery directive in the European Union makes $\mathrm{NiMH}$ batteries replace $\mathrm{Ni}-\mathrm{Cd}$ batteries for portable consumer use [23]. In advanced $\mathrm{Ni}-\mathrm{MH}$ batteries, the positive electrode is nickel hydroxide ( $\mathrm{NiOOH})$ used with optimum amounts of additives (such as $\mathrm{Co}(\mathrm{OH})_{2}, \mathrm{Y}_{2} \mathrm{O}_{3}$, graphite powders, etc.) to enhance the electrical conductivity of the cathode for higher charge efficiency [24-26]. In the last few years, nickel hydroxide production technology and its utilization techniques in $\mathrm{Ni}-\mathrm{Cd}$ and $\mathrm{Ni}-\mathrm{MH}$ batteries have increased. Because of the importance of secondary batteries, significant investments have been made in this area in the last decade. A new perspective on the mass scale production could be timely to the battery community. Ni-MH batteries have been drawing increasing attention due to their high discharge rate with relatively less heat dissipation [27, 28]. This technology has gained worldwide attention throughout the market for its ever-increasing demands for communication, space, and defense applications due to its unique features such as long-term life cycle at the profound depth of discharge.

Pioneering work of the lithium battery began in 1912 under Gilbert Lewis, but it was until early 1970 s that the first non-rechargeable lithium batteries were commercially available to the general public $[29,30]$. Attempts to develop rechargeable lithium batteries in the 1980s failed due to safety problems [31]. A breakthrough came out in 1985 when Akira Yoshino and his co-workers identified that certain qualities of petroleum coke were stable under the required electrochemical conditions [32]. These effective anode materials allowed Yoshino to develop an efficient and working LIB based on the ion transfer cell configuration [33,34]. Thus, the graphite was thus used as an anode and $\mathrm{Li}_{x} \mathrm{CoO}_{2}$ was also good enough to be a material used as a cathode [35]. These discoveries and developments ultimately led to the release of a commercial lithium battery in 1991 by SONY. Today, this chemistry has become the most promising and fastest-growing battery on the battery research ${ }^{15}$. For the past 30 years, LIBs are the most popular rechargeable energy storage devices in consumer electronics. They are the leading contenders for powering commercially viable electric 
vehicles in the near future [36]. Nearly, 70,000 major scientific journals on LIBs have been published from 1990 to 2020, but none of these articles (research/review articles) explore all the diagnostic studies of the different techniques used to investigate the LIBs and beyond. LIBs have enabled the electronics revolution and electric vehicles are beginning to take off. They are also enabling renewable energy such as wind and solar [37]. LIBs store chemical energy, delivering it in electric power with high efficiently and no exhaust emissions [38]. While LIBs are widely used in portable electronics, their implementation into larger-scale applications is hindered by the electrode materials' performance and the electrolyte [39]. Safety is also a significant concern in LIB technologies, and many high-profile examples of runaway reactions have the community searching for advanced materials with better stability $[40,41]$. For instance, cathode materials such as the layered oxides $\left(\mathrm{LiMO}_{2}\right)$ and most commercially available electrolytes exhibit a non-negligible instability at the end of the charging process [42]. To overcome these safety concerns, alternative material systems are under intense investigation to enhance safety and chemical stability over a wide range of ambient and operating temperatures [43]. As recently reported by Whittingham [44], the success of LIB over the past 30 years comes with several responsibilities such as focusing on the need for a cleaner environment for both health and climate change mitigation; emphasizing the science rather than this will make the next greatest battery. A better understanding of the reaction mechanisms, thermodynamics and kinetics and a focus on fundamental science is important. Equally important, giving enough data allows direct comparison. The LIB development did not stop with the above seminal and important discoveries, but many improvements and alternatives have since been reported [45-53].

Recently, several electrode materials and electrolyte systems have been discovered, leading to improve the energy storage materials for the benefit of society [40]. Table 1 names some electrode and electrolyte materials that have been used in the history [40].

Table 1 Electrode and electrolyte materials.

\begin{tabular}{|c|c|c|}
\hline Cathode Materials & Anode Materials & Electrolyte Materials \\
\hline $\begin{array}{l}\text { Lithium iron (II) phosphate, } \\
\text { LFP }\left(\text { LiFePO }_{4}\right)\end{array}$ & $\begin{array}{l}\text { Lithium titanate, spinel, LTO } \\
\text { nano-powder }\left(\mathrm{Li}_{4} \mathrm{Ti}_{5} \mathrm{O}_{12}\right)\end{array}$ & $\begin{array}{l}\text { Lithium aluminum titanium } \\
\text { phosphate, LATP } \\
\left(\mathrm{Li}_{1.3} \mathrm{Al}_{0.3} \mathrm{Ti}_{1.7}\left(\mathrm{PO}_{4}\right)_{3}\right)\end{array}$ \\
\hline $\begin{array}{l}\text { Lithium cobalt phosphate, } \\
\text { LCP }\left(\mathrm{LiCoPO}_{4}\right)\end{array}$ & Lithium titanate, $\mathrm{LTO}\left(\mathrm{Li}_{2} \mathrm{TiO}_{3}\right)$ & $\begin{array}{l}\text { Lithium difluoro (oxalato) } \\
\text { borate, } \mathrm{LIF}_{2} \mathrm{OB} \text {; LIODFB; LIFOB } \\
\left(\mathrm{LiBC}_{2} \mathrm{O}_{4} \mathrm{~F}_{2}\right)\end{array}$ \\
\hline $\begin{array}{l}\text { Lithium nickel manganese } \\
\text { cobalt oxide, } \mathrm{NMC} \\
\left(\mathrm{LiNi}_{0.33} \mathrm{Mn}_{0.33} \mathrm{Co}_{0.33} \mathrm{O}_{2}\right)\end{array}$ & $\begin{array}{l}\text { Lithium-aluminum alloy (Al- } \\
\text { Li) }\end{array}$ & $\begin{array}{l}\text { Lithium bis (oxalato) borate, } \\
\mathrm{LiBOB}\left(\mathrm{LiB}\left(\mathrm{C}_{2} \mathrm{O}_{4}\right)_{2}\right)\end{array}$ \\
\hline $\begin{array}{l}\text { Lithium nickel cobalt } \\
\text { aluminum oxide, } \mathrm{NCA} \\
\left(\mathrm{LiNi}_{0.8} \mathrm{Co}_{0.15} \mathrm{Al}_{0.05} \mathrm{O}_{2}\right)\end{array}$ & Tin (IV) oxide $\left(\mathrm{SnO}_{2}\right)$ & $\begin{array}{l}\text { Lithium hexafluorophosphate } \\
\text { (LiPF6) }\end{array}$ \\
\hline 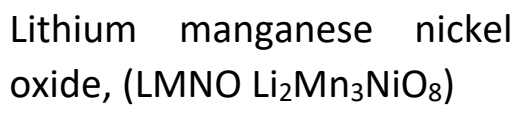 & Lithium (Li) & $\begin{array}{l}\text { Lithium trifluoromethane- } \\
\text { sulfonate, }\left(\mathrm{LiTf} \mathrm{CF}_{3} \mathrm{SO}_{3} \mathrm{Li}\right)\end{array}$ \\
\hline $\begin{array}{l}\text { Lithium nickel cobalt oxide, } \\
\text { LNCO }\left(\mathrm{LiNi}_{0.8} \mathrm{CO}_{0.2} \mathrm{O}_{2}\right)\end{array}$ & Graphite (C) & $\begin{array}{l}\text { Lithium tetrachlorogallate } \\
\left(\mathrm{LiGaCl}_{4}\right)\end{array}$ \\
\hline
\end{tabular}




\begin{tabular}{|c|c|c|}
\hline $\begin{array}{l}\text { Lithium manganese oxide, } \\
\text { LMO }\left(\mathrm{LiMn}_{2} \mathrm{O}_{4}\right)\end{array}$ & Carbon, mesoporous (C) & $\begin{array}{l}\text { Lithium tetrachloro- } \\
\text { aluminate }\left(\mathrm{LiAlCl}_{4}\right)\end{array}$ \\
\hline $\begin{array}{l}\text { Lithium manganese (III, IV) } \\
\text { oxide, LMO LiMn } \mathrm{O}_{4}\end{array}$ & Carbon (C) & $\begin{array}{l}\text { Lithium tetrafluoroborate } \\
\left(\mathrm{LiBF}_{4}\right)\end{array}$ \\
\hline $\begin{array}{l}\text { Lithium manganese dioxide } \\
\left(\mathrm{LiMnO}_{2}\right)\end{array}$ & & $\begin{array}{l}\text { Lithium perchlorate } \\
\left(\mathrm{LiClO}_{4}\right)\end{array}$ \\
\hline $\begin{array}{l}\text { Lithium nickel dioxide, LNO } \\
\left(\mathrm{LiNiO}_{2}\right)\end{array}$ & & $\begin{array}{l}\text { Lithium hexafluoroarsenate } \\
\text { (V) }\left(\mathrm{LiAsF}_{6}\right)\end{array}$ \\
\hline $\begin{array}{l}\text { Lithium trivanadate, LTV } \\
\left(\mathrm{LiV}_{3} \mathrm{O}_{8}\right)\end{array}$ & & $\begin{array}{l}\text { Lithium phosphate } \\
\text { Monobasic }\left(\mathrm{LiH}_{2} \mathrm{PO}_{4}\right)\end{array}$ \\
\hline $\begin{array}{l}\text { Lithium iron (III) oxide } \\
\left(\mathrm{LiFeO}_{2}\right)\end{array}$ & & \\
\hline $\begin{array}{l}\text { Lithium cobalt (III) oxide } \\
\left(\mathrm{LiCoO}_{2}\right)\end{array}$ & & \\
\hline Lithium molybdate $\left(\mathrm{Li}_{2} \mathrm{MoO}_{4}\right)$ & & \\
\hline Germanium (IV) sulfide $\left(\mathrm{GeS}_{2}\right)$ & & \\
\hline Manganese nickel & & \\
\hline Carbonate $\left(\mathrm{Mn}_{0.75} \mathrm{Ni}_{0.25} \mathrm{CO}_{3}\right)$ & & \\
\hline
\end{tabular}

Cathode materials, which account for about $45 \%$ of the cost of a whole battery, play an essential and decisive role in cell voltage and capacity. Disordered rock-salt (DRX) materials were shown to have facile Li transport enabled by a percolating network of Li-rich environments [54, 55]. Their ability to function without requiring cation ordering has enabled novel cathodes with remarkable chemical diversity [56]. In some cases, many new cathode materials, containing only earthabundant elements (e.g., $\mathrm{Fe}, \mathrm{Mn}$, and $\mathrm{Ti}$ ) have been developed in this category, such as $\mathrm{Li}_{1.3} \mathrm{Mn}_{0.4} \mathrm{Nb}_{0.3} \mathrm{O}_{2}$ [57], $\mathrm{Li}_{1.2} \mathrm{Mn}_{0.4} \mathrm{Ti}_{0.4} \mathrm{O}_{2}$ [58], $\mathrm{Li}_{1.2} \mathrm{Ni}_{1 / 3} \mathrm{Ti}_{1 / 3} \mathrm{Mo}_{2 / 15} \mathrm{O}_{2}$ [59], $\mathrm{Li}_{4} \mathrm{Mn}_{2} \mathrm{O}_{5}$ [60], and $\mathrm{Li}_{2} \mathrm{FeV}_{0.5} \mathrm{Ti}_{0.5} \mathrm{O}_{4}[61]$ as well as their fluorinated variants [62-66].

The objective of this perspective article is to extend knowledge in the fields of materials chemistry such as the improvement of the capacity of LIBs in ways that will make green energy more accessible and commercially viable [67]. Building a better LIB involves addressing several factors simultaneously. For instance, keeping the battery's cathode electrically and ionically conductive to making sure that the battery stays safe after many cycles [68]. A recent discovery published in the article Nature reports the development of a new cathode coating by using an oxidative chemical vapor deposition technique that can help solve several potential issues with LIBs all in one stroke [69]. The polymer fabricated in this discovery called PEDOT consists of nickel-manganese-cobalt (NMC) cathode material, encapsulated with a sulfur-containing polymer [70]. This polymer provides the cathode a layer of protection from the battery's electrolyte as the battery charges and discharges. A recent article by Divakaran et al. [71] reviews a rational design on materials for developing next generation LIB. Divakaran et al. presents the historical and recent advancements in cathode and anode materials including the future scope of the lithium nickel manganese cobalt oxide cathode. The review focuses also on the role of technological advancements in nanomaterials as a performance improvement technique for new novel anode and cathode materials as well as on the discussion about lithium based and beyond lithium-based anode materials. In addition, the review offers rational cell and material design, perspectives, and future challenges to promote the 
application of these materials in practical lithium-ion batteries [71]. With the coating PEDOT application, it is expected that the NMC-containing battery could either run at higher voltages, thus increasing their energy output, lifespans, or both. This work is reported in the journals [69, 72].

The progress in energy storage requires new ways of thinking about LIBs and the fundamental limitations that different material chemistries impose. Research in electrochemistry presents a potential breakthrough advancement needed for the electrode and solid electrolyte materials to play a significant role in safer LIBs with longer life and higher efficiency. This would provide an explicit new understanding of the mechanism of Li-ion conduction and the through-space distance measurement between lithium spins in different environments [73, 74]. The applications and further development of the different techniques during the last 30 years of diagnostic studies in LIBs and beyond cover critical technological developments and scientific challenges for a broad range of LIBs and beyond. The information that can be derived by applying different techniques to LIBs and beyond can be used to compare many families of suitable materials. Over the past decades, there have been many projections on the future depletion of the fossil fuel reserves on Earth as well as the rapid increase in green-house gas emissions [75]. There is clearly an urgent need for the development of renewable energy technologies [76]. Reliance on fossil-fuel energy led to countless resource wars worldwide and has resulted in the climate crisis we now face. Renewable energy sources such as wind or photovoltaic are intermittent, and their production peaks do not always follow the increasing demand. Therefore, storing green energy is essential to moving away from fossil fuels [77]. On a different frontier, the growth, and manipulation of materials on the nanometer scale have progressed rapidly [78]. Energy is the basic framework unifying the developing technologies for alternative green energy storage and conversion devices such as batteries, fuel cells, solar cells for transportation, stationary power and for distributed power generation applications [79]. This framework is the only framework of its kind that allows a consistent treatment of the LIBs from electrodes and electrolytes to surfaces or solid-state electrodeelectrolyte interface. LIBs are currently the staple of the video battery industry, and they have improved our life dramatically. LIBs are approaching their theoretical limits on achievable energy density and specific energy [36]. If the market demand rises for even higher energy cells, then, the community must consider new technologies. The drawback of LIBs is due in part to the use of liquid organic electrolytes. While these organic electrolytes are necessary to the battery, they are highly flammable [80]. However, what we need for the future is a new battery technology called solidstate battery (SSB), which promises greater safety, longer life, and faster charging [81]. This is because SSBs contain non-flammable liquid electrolytes. In contrast, LIBS are charged with electricity generated when lithium-ion travels from cathode to anode. SSB technology is not new [82]. Michael Faraday discovered the solid electrolytes silver sulfide and lead fluoride, which laid the foundation for solid-state research [83]. In the late 1950s, efforts were initiated to develop a SSB, which failed due to design limitations [84]. LIBs are at the center of the advanced rechargeable batteries and the scientific community has expanded an enormous effort to search for new electrode and electrolyte materials to enhance the amount of energy stored in electrochemical cells [85].

LIB development has a promising future as it lays in the intersection of improvement of costefficient energy storage, an ability to wean economies out of oil dependence, and critical components needed to fight and curb global warming [86]. To look at the future of LIB development, we must look at the previous techniques and tools used in the battery science formation and how 
those tools have spilled over to other areas of physical science [87]. We also must analyze the basic structural fundamentals of battery science and see if they still hold up to 30 years of development and research or if they should be modified or thrown out. LIB is very reactive and can withstand and achieve a high voltage rate. This makes it an interesting and an excellent choice for the battery revolution. Since, the growing needs of society are getting more and more demanding, LIBs are falling short due to the incapability of satisfying certain areas of societal needs. This shows that the question that one should ask is: Would LIBs still be the future knowing that obviously it does not satisfy major needs of interest? Researchers are looking forward to improving or increasing energy density for other lithium-based batteries other than LIB, such as lithium sulfur (Li-S) batteries and lithium-oxygen $\left(\mathrm{Li}^{-\mathrm{O}_{2}}\right)$ [49]. More recently, to provide more sustainable energy storage solutions, advancements have been made on sodium-Ion batteries (NIBs), potassium-ion batteries (KIBs) [45], and magnesium-ion batteries (MIBs) [88]. These sustainable energies storage solutions with the use of NIBs, KIBs and MIBs are much more present and abundant than lithium. Moreover, they are promising prospects for large-scale grid energy storage. These facts are enough to conclude that LIBs are far from being the one lithium-based battery to resolve specific problems. Thus, the question of it being the future is inadequate! Researchers are looking for replacements of LIBs and researches show that many batteries can be candidates [44]. For example, Na-based batteries are candidates for large-scale stationary energy storage applications. Other potential candidates such as the spinel $\mathrm{Li}_{1-x} \mathrm{Mn}_{2} \mathrm{O}_{4}$ and the disordered rock-salt Li-Excess battery materials have been discovered to be ever-improving energy storage materials for the benefit of society [89-91]. LIBs are generally safe, but only so long as there are no defects and the batteries are not damaged. This presents some issues because a squandering of LIB can cause a lot of damage. We recall the incident with Samsung Galaxy Note 7, where the problem came from a slight flaw in the battery's fabrication, which caused a lot of damage. The battery inside the phone was a lithium-based battery which means that it can present safety issues. Even though LIBs are failing to satisfy societal needs is the reason why researchers are looking beyond LIBS, it is important to mention that it has its advantages. LIBs are by far the most convenient ion-based battery in the industry, making them a product of preference among the other batteries [92]. All electronic products now require a LIB for basic functioning. The practical benefits of the LIB are, without a doubt, compelling. The batteries are lighter in weight than most rechargeable battery alternatives, they hold their charge well, they have no memory effect, and they can handle hundreds of cycles of discharging/charging [46].

The cost of LIBs used to be high and now we are seeing a decrease in cost over the last few years. It's so happens that LIB has a lifespan for a large-capacity battery pack and can be as long as eight or more years [93]. This shows that a LIB is the ideal battery when it comes to longevity because today, we need a battery that has a long lifespan for it to satisfy the modern society's needs in that area. LIBs compared to other batteries have the least impact on the environment. More and more research is being conducted and has been done to ever-improving battery understanding, especially lithium based-battery. The next step for the scientific community is to change perspective and start focusing on the other types of batteries that can satisfy societal needs rather than spending a lot of effort on LIBs again. It is about time to change direction and to use other techniques of application to other types of batteries to fill in the blank of what LIBs can no longer do. Four perspectives characterize the evolution from the conventional to the advanced LIBs (e.g., Li-rich transition metal oxide and Ni-rich transition metal oxide batteries), to the state of-the-art LIBs (e.g., Li-air, Li-sulfur batteries (LSBs), organic electrode batteries, solid-state batteries, and $\mathrm{Li}-\mathrm{CO}_{2}$ batteries), and to the 
hybridized LIBs (e.g., metal halide perovskite batteries). LSB should be a promising candidate for the next generation of rechargeable batteries, but they are not without problems [94]. The efficiency of charge transfer is low for lithium, and lithium batteries tend to grow dendrites, thin branching crystals when charging that do not disappear when discharged. Sulfur is the right battery of choice because it is inexpensive and has a high-charge capacity and a high energy density. For this reason, LSB has more energy. However, an LSB forms an inorganic coating in the battery that is brittle and cannot tolerate changes in volume [95]. In LSB, the electrolyte dries up and the bulk lithium corrodes. The lithium dendrites that form can create short circuits and other safety hazards [96]. Switching LIB from a flammable liquid electrolyte to a solid is not an easy task as lithium ions in solids are less mobile than in liquids. This lower mobility limits the battery performance in terms of charge and discharge rate. Scientists have been looking for materials that could enable all-SSBs. Recently, materials such as, $\mathrm{LiTi}_{2}\left(\mathrm{PS}_{4}\right)_{3}$ or LTPS have been discovered [97]. LTPS has the highest lithium diffusion coefficient ever measured in a solid. The lithium mobility comes directly from the unique crystal structure of LTPS. This mechanism opens new perspectives in the field of lithium ion conductors, and beyond LTPS, opens an avenue toward the search for new materials with similar diffusion mechanisms. This discovery is an important step in the understanding of materials needed for all-solid-state batteries of the future.

In addition of portable electronic devices, more perspectives on LIBs upon future developing techniques include in aerospace with applications in satellites and aviation [98].

Recently, Zubi et al. reported the LIBs technology that has the potential to be used in power supply systems, off-grid and grid-connected. Substantial improvements have been achieved in medical devices, such as in hearing aids, by exploiting the advances in lithium battery technology. This development has also guaranteed miniaturized, reliable, high density and hermetically sealed rechargeable power sources for highly integrated and size-limited low power implantable devices in applications such as drug-delivery, glucose sensing, and neuro-stimulation [99]. The use of LIBs in medical devices has been explored, among others, by the US Food and Drug Administration [100]. Many self-powered micro-electronics, such as miniature transistors, sensors and actuators also integrate tiny LIBs [101]. Furthermore, as professionals continue to demand more powerful, efficient, and comfortable tools to work with, LIBs offer outstanding specific energy and power together with low self-discharge rates [102]. Finally, Li-ion cells can also be found in wearable technology products, flashlights, radio-controlled toys, solar LED systems and wireless vacuum cleaners, among others [98].

\section{Acknowledgments}

The author would like to thank Drs. Thibault Charpentier and Vincent Battaglia, and Professors Robert Messinger and Bingwen Hu for helpful discussion. The author acknowledges the financial support from the City University of New York GRANT CCRG \# 1517, PSC-CUNY RESEARCH AWARD \# 62654-00 50, and CUNY RESEARCH SCHOLAR PROGRAM (2020-2021). The author appreciates the mentee' students Fambougouri Diane, Daniel Bosah, Lamisa Rusmeha, Aissata Diop, Malik Pernarh, and Paulin Dongomale for reading the manuscript and helping in editing. The contents of this paper are solely the responsibility of the author and do not represent the official views of the NIH. 


\section{Author Contributions}

Eugene Mananga: Conceptualization, Writing - original draft, Writing - review \& editing.

\section{Competing Interests}

The authors have declared that no competing interests exist.

\section{Biography}

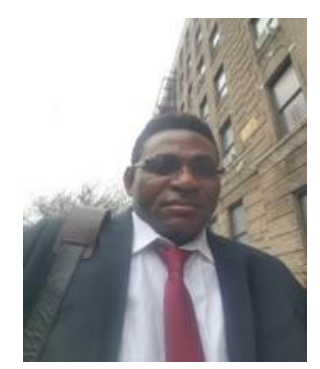

Dr Eugene Mananga is a Doctoral Faculty in Physics \& Chemistry Ph.D' Programs at the Graduate Center of the City University of New York (CUNY), where he is the recipient of the 2017 Henry Wasser Award in Physics, and the Program Director of STEM-Grants for the CUNY Academy for Humanities and Sciences. He is an Assistant Professor of Physics and Nuclear Medicine at Bronx Community College of CUNY and an Adjunct Professor of Applied Physics at New York University. Professor Mananga' s research and service efforts have been recognized by several awards including the 2018 Distinguished Scientist Award from the American Chemical Society (New York Section) for "Contributions and Advanced Studies in the Theory of Spin Dynamics in Solid-State Nuclear Magnetic Resonance and Quantum Mechanics", the 2018 PKAL STEM LEADERSHIP INSTITUTE II, the Laureate of 2017 Henry Wasser Award in Physics from the CUNY Academy of Humanities and Sciences in recognition of "Outstanding Scholarship and Academic Performance", and his scientific contribution in the field of Nuclear Magnetic Resonance was honored in the article dedicated to celebrate the 70th anniversary (1946 - 2016) of the Russian Academic of Sciences.

During the years 2021, 2020 and 2019, Dr. Mananga was selected to participate in the US Department of Energy Visiting Faculty Program at Lawrence Berkeley National Laboratory (Berkeley Lab, 2021 \& 2020) and at Argonne National Laboratory (University of Chicago, 2019) to work on problems related to energy storage and technology. Part of his current research interest is in the field of electrochemical energy storage with the focus on the characterization of the electrode materials for rechargeable batteries. Eugene completed his Ph. D in Physics from the City University of New York (with Distinguished Professor Steven Greenbaum, Hunter College) and holds 6 additional graduate degrees and training from various institutions including Harvard University, Massachusetts Institute of Technology (MIT), Massachusetts General Hospital (MGH), and City College of New York. Eugene did his postdoctoral studies in the National High Magnetic Field Laboratory of USA, Harvard Medical School and MGH. Prior to joining Harvard-MGH, Eugene was an "Ingenieur de Recherche" in the French Alternative Energies and Atomic Energy Commission (CEA-SACLAY, NEUROSPIN). Dr. Mananga current research interests include Condensed Matter Physics, Atomic and Molecular Physics, Nuclear Magnetic Resonance, Energy Materials, Medical Physics, Radiological Sciences and Nuclear Medicine. Currently, he is focused on advancing theory, 
simulation and methodology in Solid-State Nuclear Magnetic Resonance, Spin Dynamics, Quantum Physics, Imaging Science, Medical Physics and Nuclear Medicine.

\section{References}

1. Flick J, Welakuh DM, Ruggenthaler M, Appel H, Rubio A. Light-matter response in nonrelativistic quantum electrodynamics. ACS Photonics. 2019; 6: 2757-2778.

2. Jayakody JR, Stallworth PE, Mananga ES, Farrington-Zapata J, Greenbaum SG. High pressure NMR study of water self-diffusion in NAFION-117 membrane. J Phys Chem B. 2004; 108: 42604262.

3. Jayakody JR, Khalfan A, Mananga ES, Greenbaum SG, Dang TD, Mantz R. NMR investigation of water and methanol transport in sulfonated polyareylenethioethersulfones for fuel cell applications. J Power Sources. 2006; 156: 195-199.

4. Hu X, Lou X, Li C, Ning Y, Liao Y, Chen Q, et al. Facile synthesis of the Basolite F300-like nanoscale Fe-BTC framework and its lithium storage properties. RSC Adv. 2016; 6: 114483-114490.

5. Pecher O, Carretero-González J, Griffith KJ, Grey CP. Materials' methods: NMR in battery research. Chem Mater. 2017; 29: 213-242.

6. Wang L, Wang J, Zuo P. Probing battery electrochemistry with in operando synchrotron X-ray imaging techniques. Small Methods. 2018; 2: 1700293.

7. Deng Y, Dong S, Li Z, Jiang H, Zhang X, Ji X. Applications of conventional vibrational spectroscopic methods for batteries beyond Li-ion. Small Methods. 2018; 2: 1700332.

8. Li W, Li M, Hu Y, Lu J, Lushington A, Li R, et al. Synchrotron-based X-ray absorption fine structures, $\mathrm{X}$-ray diffraction, and $\mathrm{X}$-ray microscopy techniques applied in the study of lithium secondary batteries. Small Methods. 2018; 2: 1700341.

9. Qu D, Wang G, Kafle J, Harris J, Crain L, Jin Z, et al. Electrochemical impedance and its applications in energy-storage systems. Small Methods. 2018; 2: 1700342.

10. Liu X, Gu L. Advanced transmission electron microscopy for electrode and solid-electrolyte materials in lithium-ion batteries. Small Methods. 2018; 2: 1800006.

11. Ren $Y$, Zuo X. Synchrotron X-ray and neutron diffraction, total scattering, and small-angle scattering techniques for rechargeable battery research. Small Methods. 2018; 2: 1800064.

12. Lu J. Forum on "Characterization Techniques for Li-Ion Batteries and Beyond". Small Methods. 2018; 2: 1800248.

13. Li M, Lu J, Chen Z, Amine K. 30 years of lithium-ion batteries. Adv Mater. 2018; 30: 1800561.

14. Lin F, Liu Y, Yu X, Cheng L, Singer A, Shpyrko OG, et al. Synchrotron X-ray analytical techniques for studying materials electrochemistry in rechargeable batteries. Chem Rev. 2017; 117: 1312313186.

15. Afework B, Hanania J, Jenden J, Stenhouse K, Toor J, Donev J. Energy Education [Internet]. Available from: https://energyeducation.ca/encyclopedia/Battery.

16. Alessandro Volta. This month in physics history [Internet]. College Park, MA: American Physical Society; 2006.

Available

from: https://www.aps.org/publications/apsnews/200603/history.cfm.
17. Gaston
Planté.
Chicago,
IL:
Britannica.
Available
from:

https://www.britannica.com/biography/Gaston-Plante. 
18. Heth CL. Energy on demand: A brief history of the development of the battery. Substantia. 2019; 3: 77-86.

19. BOBBY. Ernst Waldemar Jungner and his portable batteries [Internet]. Tonawanda, NY: UPS Battery Center; 2014. Available from: https://www.upsbatterycenter.com/blog/waldemarjungner/.

20. Mii K, Amano M. R \& D of hydrogen absorbing alloys in Japan. ACTA METALL SIN ENGL. 2009; 10: 249-255.

21. Empire City Auto Parts. Nickel-metal hydride battery [Internet]. Blaine, MN: Empire City Auto Parts; 2020. Available from: https://empirecityautoparts.com/products/parts/nickel-metalhydride-battery/.

22. The Economist. In search of the perfect battery [Internet]. London: The Economist; 2008. Available from: https://www.economist.com/technology-quarterly/2008/03/08/in-search-ofthe-perfect-battery.

23. The European Parliament and The Council of The European Union. Directive 2006/66/EC of the European Parliament and of the Council of the 6 September 2006 on batteries and accumulators and repealing directive 91/157/EEC [Internet]. Luxembourg: Official Journal of the European Union; 2006. Available from: https://eur-lex.europa.eu/eli/dir/2006/66/oj.

24. Ash B, Nalajala VS, Popuri AK, Subbaiah T, Minakshi M. Perspectives on nickel hydroxide electrodes suitable for rechargeable batteries: Electrolytic vs. chemical synthesis routes. Nanomaterials. 2020; 10: 1878.

25. Takaki M, Fujioka N, Ikoma M. Development of small and medium sized sealed-type nickel/metal-hydride battery for electric vehicle. In proceedings of the 14th International Electric Vehicle Symposium; 1997 December 15th-17th; Orlando, FL, USA. Tokyo: CiNii Articles.

26. Ohta K, Hayashi K, Matsuda H, Toyoguchi Y, Ikoma M. Nickel hydroxide: Improvement of charge efficiency at high temperature. In Hydrogen and Metal Hydride Batteries. Pennington, NJ: The Electrochemical Society; 1994. pp.296-302.

27. McBreen J. Nickel Hydroxides. In Handbook of Battery Materials. Weinheim: V.C.H Publications; 1997.

28. McBreen J. The nickel oxide electrode. In Modern Aspects of Electrochemistry No. 21. New York, NY: Plenum Publishing Corporation; 1989. pp.29-58.

29. BU-204: How do Lithium Batteries Work? Available from: https://batteryuniversity.com/learn/article/lithium based batteries.

30. Is Lithium-ion the Ideal Battery? Available from: https://batteryuniversity.com/learn/archive/is lithium ion the ideal battery.

31. Energy without Carbon. Lithium ion battery [Internet]. Available from: http://www.energywithout-carbon.org/LithiumlonBattery.

32. Goodenough JB, Whittingham MS, Yoshino A. Lithium-ion batteries [Internet]. Stockholm: Royal Swedish Academy of Sciences; 2019. Available from: https://www.nobelprize.org/uploads/2019/10/advanced-chemistryprize2019.pdf.

33. Yoshino A. The birth of the lithium-ion battery. Angew Chem Int Ed. 2012; 51: 5798-5800.

34. Yoshino A, Sanechika K, Nakajima T. Secondary battery. Alexandria, VA: United States Patent and Trademark Office; 1987; US4668595A.

35. Goodenough JB, Kim Y. Challenges for rechargeable Li batteries. Chem Mater. 2010; 22: $587-$ 603. 
36. Ding Y, Cano ZP, Yu A, Lu J, Chen Z. Automotive Li-ion batteries: Current status and future perspectives. Electrochem Energ Rev. 2019; 2: 1-28.

37. Diouf B, Pode R. Potential of lithium-ion batteries in renewable energy. Renew Energ. 2015; 76: 375-380.

38. Chen $\mathrm{H}$, Cong TN, Yang W, Tan C, Li Y, Ding Y. Progress in electrical energy storage system: A critical review. Prog Nat Sci. 2009; 19: 291-312.

39. Mishra K, Yadav N, Hashmi SA. Recent progress in electrode and electrolyte materials for flexible Sodium-ion batteries. J Mater Chem A. 2020; 8: 22507-22543.

40. Chabal YJ, Cho K, Hinkle CL. Safer high-performance electrodes, solid electrolytes, and interface reactions for Lithium-ion batteries [Internet]. Shanghai: Sigma-Aldrich LLC. Available from: https://qaci.sial.com/technical-documents/articles/materials-science/safer-high-

performance-electrodes-solid-electrolytes.html; also LIB Materials available from: aldrich.com/lib.

41. Wang $Q$, Jiang $L, Y u$ Y, Sun J. Progress of enhancing the safety of Lithium ion battery from the electrolyte aspect. Nano Energy. 2019; 55: 93-114.

42. Kokalj A, Dominko R, Mali G, Meden A, Gaberscek M, Jamnik J. Beyond one-electron reaction in Li cathode materials: Designing $\mathrm{Li}_{2} \mathrm{Mn}_{x} \mathrm{Fe}_{1-x} \mathrm{SiO}_{4}$. Chem Mater. 2007; 19: 3633-3640.

43. Gong $\mathrm{ZL}$, $\mathrm{Li} Y X$, Yang $\mathrm{Y}$. Synthesis and characterization of $\mathrm{Li}_{2} \mathrm{Mn}_{\mathrm{x}} \mathrm{Fe}_{1-\mathrm{x}} \mathrm{SiO}_{4}$ as a cathode material for lithium-ion batteries. Electrochem Solid State Lett. 2006; 9: A542.

44. Whittingham MS. Special editorial perspective: Beyond Li-ion battery chemistry. Chem Rev. 2020; 120: 6328-6330.

45. Nitta N, Wu F, Lee JT, Yushin G. Li-ion battery materials: Present and future. Mater Today. 2015; 18: 252-264.

46. Tarascon JM, Armand M. Issues and challenges facing rechargeable lithium batteries. Nature. 2001; 414: 359-367.

47. Thangadurai V, Narayanan S, Pinzaru D. Garnet-type solid-state fast Li ion conductors for Li batteries: Critical review. Chem Soc Rev. 2014; 43: 4714-4727.

48. Yu C, Ganapathy S, Van Eck ER, Wang H, Basak S, Li Z, et al. Accessing the bottleneck in all-solid state batteries, Lithium-ion transport over the solid-electrolyte-electrode interface. Nat Commun. 2017; 8: 1086.

49. Xu K. Electrolytes and interphases in Li-ion batteries and beyond. Chem Rev. 2014; 114: 1150311618.

50. Bakhmutov VI. Solid-state NMR in materials science: Principles and applications. 1st ed. Boca Raton, FL: CRC press; 2011.

51. Chandran CV, Heitjans P. Solid-state NMR studies of lithium ion dynamics across materials classes. Annu Rep NMR Spectrosc. 2016; 89: 1-102.

52. Rangasamy E, Liu Z, Gobet M, Pilar K, Sahu G, Zhou W, et al. An iodide-based Li7P2S8I superionic conductor. J Am Chem Soc. 2015; 137: 1384-1387.

53. Kamaya N, Homma K, Yamakawa Y, Hirayama M, Kanno R, Yonemura M, et al. A lithium superionic conductor. Nat Mater. 2011; 10: 682-686.

54. Ji H, Urban A, Kitchaev DA, Kwon DH, Artrith N, Ophus C, et al. Hidden structural and chemical order controls lithium transport in cation-disordered oxides for rechargeable batteries. Nat Commun. 2019; 10: 592. 
55. Lee J, Urban A, Li X, Su D, Hautier G, Ceder G. Unlocking the potential of cation-disordered oxides for rechargeable lithium batteries. Science. 2014; 343: 519-522.

56. Urban A, Lee J, Ceder $G$. The configurational space of rocksalt-type oxides for high-capacity lithium battery electrodes. Adv Energy Mater. 2014; 4: 1400478.

57. Yabuuchi N, Takeuchi M, Nakayama M, Shiiba H, Ogawa M, Nakayama K, et al. High-capacity electrode materials for rechargeable lithium batteries: $\mathrm{Li}_{3} \mathrm{NbO}_{4}$-based system with cationdisordered rocksalt structure. Proc Natl Acad Sci U S A. 2015; 112: 7650-7655.

58. Yabuuchi N, Nakayama M, Takeuchi M, Komaba S, Hashimoto $Y$, Mukai T, et al. Origin of stabilization and destabilization in solid-state redox reaction of oxide ions for lithium-ion batteries. Nat Commun. 2016; 7: 13814.

59. Lee J, Seo DH, Balasubramanian M, Twu N, Li X, Ceder G. A new class of high capacity cationdisordered oxides for rechargeable lithium batteries: Li-Ni-Ti-Mo oxides. Energy Environ Sci. 2015; 8: 3255-3265.

60. Freire M, Kosova NV, Jordy C, Chateigner D, Lebedev OI, Maignan A, et al. A new active Li-MnO compound for high energy density Li-ion batteries. Nat Mater. 2016; 15: 173-177.

61. Chen R, Witte R, Heinzmann R, Ren S, Mangold S, Hahn H, et al. Identifying the redox activity of cation-disordered Li-Fe-V-Ti oxide cathodes for Li-ion batteries. Phys Chem Chem Phys. 2016; 18: 7695-7701.

62. Chen R, Ren S, Knapp M, Wang D, Witter R, Fichtner M, et al. Disordered lithium-rich oxyfluoride as a stable host for enhanced $\mathrm{Li}^{+}$intercalation storage. Adv Energy Mater. 2015; 5: 1401814.

63. Takeda N, Hoshino S, Xie L, Chen S, Ikeuchi I, Natsui R, et al. Reversible Li storage for nanosize cation/anion-disordered rocksalt-type oxyfluorides: $\mathrm{LiMoO}_{2}$-xLiF $(0 \leq x \leq 2)$ binary system. J Power Source. 2017; 367: 122-129.

64. Lee J, Papp JK, Clément RJ, Sallis S, Kwon DH, Shi T, et al. Mitigating oxygen loss to improve the cycling performance of high capacity cation-disordered cathode materials. Nat Commun. 2017; 8: 981.

65. House RA, Jin L, Maitra U, Tsuruta K, Somerville JW, Förstermann DP, et al. Lithium manganese oxyfluoride as a new cathode material exhibiting oxygen redox. Energy Environ Sci. 2018; 11: 926-932.

66. Lee J, Kitchaev DA, Kwon DH, Lee CW, Papp JK, Liu YS, et al. Reversible $\mathrm{Mn}^{2+} / \mathrm{Mn}^{4+}$ double redox in lithium-excess cathode materials. Nature. 2018; 556: 185-190.

67. Pippa Stevens. The battery decade: How energy storage could revolutionize industries in the next 10 years [Internet]. Englewood Cliffs, NJ: CNBC LLC; 2019. Available from: https://www.cnbc.com/2019/12/30/battery-developments-in-the-last-decade-created-aseismic-shift-that-will-play-out-in-the-next-10-years.html.

68. European Coatings. New coating could have big implications for lithium batteries [Internet]. Hannover: Vincentz Network GmbH \& Co. KG; 2019. Available from: https://www.europeancoatings.com/articles/archiv/new-coating-could-have-big-implications-for-lithium-batteries.

69. Xu GL, Liu Q, Lau KK, Liu Y, Liu X, Gao H, et al. Building ultraconformal protective layers on both secondary and primary particles of layered lithium transition metal oxide cathodes. Nat Energy. 2019; 4: 484-494.

70. Gleason KK. Nanoscale control by chemically vapour-deposited polymers. Nat Rev Phys. 2020; 2: 347-364. 
71. Divakaran AM, Minakshi M, Bahri PA, Paul S, Kumari P, Divakaran AM, et al. Rational design on materials for developing next generation Lithium-ion secondary battery. Prog Solid State Ch. 2020. Doi: 10.1016/j.progsolidstchem.2020.100298.

72. Sagoff J. New Argonne coating could have big implications for lithium batteries [Internet]. Available from: https://www.anl.gov/article/new-argonne-coating-could-have-bigimplications-for-lithium-batteries.

73. Messinger RJ, Ménétrier M, Salager E, Boulineau A, Duttine M, Carlier D, et al. Revealing defects in crystalline lithium-ion battery electrodes by solid-state NMR: Applications to LiVPO ${ }_{4} \mathrm{~F}$. Chem Mater. 2015; 27: 5212-5221.

74. Kandhasamy S, Nallathamby K, Minakshi M. Role of structural defects in olivine cathodes. Prog Solid State Ch. 2012; 40: 1-5.

75. Climate Change Indicators. Climate change indicators: Greenhouse gases [Internet]. Washington, DC: United States Environmental Protection Agency; 2020. Available from: https://www.epa.gov/climate-indicators/greenhouse-gases.

76. Energy Factor. What an energy-efficient world looks like [Internet]. Irving, TX: ExxonMobil; 2020. Available from: https://energyfactor.exxonmobil.com/insights/focus/energy-efficientworld/.

77. The batteries that could make fossil fuels obsolete. Available from: https://www.bbc.com/future/article/20201217-renewable-power-the-worlds-largest-battery.

78. Chen X, Li C, Grätzel M, Kostecki R, Mao SS. Nanomaterials for renewable energy production and storage. Chem Soc Rev. 2012; 41: 7909-7937.

79. National Research Council, National Academy of Engineering, National Academy of Sciences, America's Energy Future Panel on Electricity from Renewable Resources. Electricity from renewable resources: Status, prospects, and impediments. Washington, DC: The National Academies Press; 2010.

80. Chatterjee K, Pathak AD, Lakma A, Sharma CS, Sahu KK, Singh AK. Synthesis, characterization and application of a non-flammable dicationic ionic liquid in Lithium-ion battery as electrolyte additive. Sci Rep. 2020; 10: 9606.

81. Hall C. Future batteries, coming soon: Charge in seconds, last months and power over the air [Internet]. Ascot: Pocket-lint; 2021. Available from: https://www.pocketlint.com/gadgets/news/130380-future-batteries-coming-soon-charge-in-seconds-lastmonths-and-power-over-the-air.

82. Reisch MS. Solid-state batteries inch their way toward commercialization. Chem Eng News. 2017; 95: 19-21.

83. Nikkei staff. Toyota's game-changing solid-state battery en route for 2021 debut [Internet]. Tokyo: Nikkei staff; 2020. Availale from: https://asia.nikkei.com/Spotlight/Most-read-in2020/Toyota-s-game-changing-solid-state-battery-en-route-for-2021-debut.

84. Beacham F. The days of Lithium-ion batteries are numbered [Internet]. Hitchin: The Broadcast Bridge; 2019. Available from: https://www.thebroadcastbridge.com/content/entry/13450/the-days-of-lithium-ionbatteries-are-numbered.

85. Cowan AJ, Hardwick $\sqcup$. Advanced spectroelectrochemical techniques to study electrode interfaces within Lithium-ion and lithium-oxygen batteries. Annu Rev Anal Chem. 2019; 12: 323346. 
86. Puiu T. The Future is bright for Lithium-ion batteries [Internet]. Lindau: Lindau Nobel Laureate Meetings; 2020. Available from: https://www.lindau-nobel.org/blog-the-future-is-bright-forlithium-ion-batteries/.

87. Kim T, Song W, Son DY, Ono LK, Qi Y. Lithium-ion batteries: Outlook on present, future, and hybridized technologies. J Mater Chem A. 2019; 7: 2942-2964.

88. Zhan Y, Zhang W, Lei B, Liu H, Li W. Recent development of Mg ion solid electrolyte. Front Chem. 2020; 8: 125.

89. Leifer N, Schipper F, Erickson EM, Ghanty C, Talianker M, Grinblat J, et al. Studies of spinel-tolayered structural transformations in $\mathrm{LiMn}_{2} \mathrm{O}_{4}$ electrodes charged to high voltages. J Phys Chem C. 2017; 121: 9120-9130.

90. Wang R, Li X, Liu L, Lee J, Seo DH, Bo SH, et al. A disordered rock-salt Li-excess cathode material with high capacity and substantial oxygen redox activity: $\mathrm{Li}_{1.25} \mathrm{Nb}_{0.25} \mathrm{Mn}_{0.5} \mathrm{O}_{2}$. Electrochem commun. 2015; 60: 70-73.

91. Clément RJ, Kitchaev D, Lee J, Ceder G. Short-range order and unusual modes of nickel redox in a fluorine-substituted disordered rocksalt oxide lithium-ion cathode. Chem Mater. 2018; 30: 6945-6956.

92. Chen $T$, Jin $Y$, Lv H, Yang A, Liu M, Chen B, et al. Applications of lithium-ion batteries in gridscale energy storage systems. Trans Tianjin Univ. 2020; 26: 208-217.

93. Hearst Autos Research. Electric car battery life: Everything you need to know [Internet]. Boone, IA: Car and Driver; 2020. Available from: https://www.caranddriver.com/research/a31875141/electric-car-battery-life/.

94. Wu F, Maier J, Yu Y. Guidelines and trends for next-generation rechargeable lithium and lithiumion batteries. Chem Soc Rev. 2020; 49: 1569-1614.

95. Jang J, Oh J, Jeong H, Kang W, Jo C. A review of functional separators for lithium metal battery applications. Materials. 2020; 13: 4625.

96. Li W, Yao H, Yan K, Zheng G, Liang Z, Chiang YM, et al. The synergetic effect of lithium polysulfide and lithium nitrate to prevent lithium dendrite growth. Nat Commun. 2015; 6: 7436.

97. Di Stefano D, Miglio A, Robeyns K, Filinchuk Y, Lechartier M, Senyshyn A, et al. Superionic diffusion through frustrated energy landscape. Chem. 2019; 5: 2450-2460.

98. Zubi G, Dufo-López R, Carvalho M, Pasaoglu G. The lithium-ion battery: State of the art and future perspectives. Renew Sust Energ Rev. 2018; 89: 292-308.

99. Li P, Bashirullah R. A wireless power interface for rechargeable battery operated medical implants. IEEE Trans Circuits Syst II Express Briefs. 2007; 54: 912-916.

100.US Food \& Drug Administration. Batteries in medical devices [Internet]. [cited date 2017 March]. Available from: www.fda.gov.

101. Wang Y, Liu B, Li Q, Cartmell S, Ferrara S, Deng ZD, et al. Lithium and lithium ion batteries for applications in microelectronic devices: A review. J Power Sources. 2015; 286: 330-345.

102.Grainger Editorial Staff. Cordless tools powered by Li-ion [Internet]. Lake County, IL: W. W. Grainger; 2017 [cited date 2017 February 15th]. Available from: https://www.grainger.com/content/supplylink-lithium-ion-power-tools-benefits. 


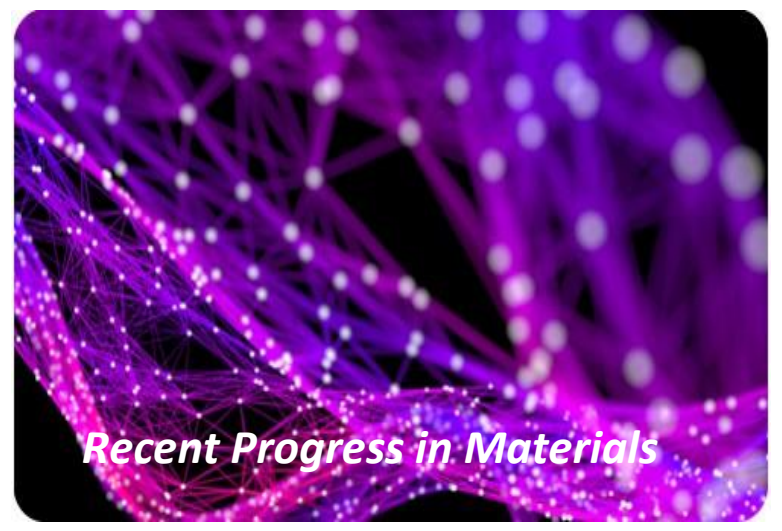

Enjoy Recent Progress in Materials by:

\title{
1. Submitting a manuscript
}

2. Joining in volunteer reviewer bank

3. Joining Editorial Board

4. Guest editing a special issue

For more details, please visit:

http://www.lidsen.com/journals/rpm

i

\begin{abstract}
'I profoundly invigorate researchers in applied physics, chemistry, materials science, nanomaterials, electrochemistry, battery, capacitor, and fuel cell communities to submit their excellent works to the Recent Progress in Materials which is one of the most promising journal to publish the most reliable source of information on discoveries and current developments in battery, fuel cells, and material chemistry. Energy storage will be critically important as we work towards sustainable living. Developing cost-effective ways to store large amounts of electricity (and decarbonization) is a significant area of research. The current generation lithium batteries are widely used in laptop computers and in electric vehicles. Undoubtedly, developing the lithium battery system with improved long-life cycle, safety issues and stability are crucial. To those who are inspecting new incursion into the Recent Progress in Materials, I stimulate you to join a body of scientists who like to push their intuition to the boundaries.
\end{abstract}

